\title{
Crosstalk between Melanin Concentrating Hormone and Endocrine Factors: Implications for Obesity
}

\author{
Eva Prida ${ }^{1}$, Sara Fernández-González ${ }^{1}$, Verónica Pena-León ${ }^{1,2}$, Raquel Pérez-Lois ${ }^{1,2}$, Johan Ferno ${ }^{3}$, \\ Luisa María Seoane ${ }^{1,2} \mathbb{( D}$, Mar Quiñones ${ }^{2,4, * \mathbb{C}}$ and Omar Al Massadi $1,2, *(\mathbb{C})$
}

1 Instituto de Investigación Sanitaria de Santiago de Compostela, Complexo Hospitalario Universitario de Santiago (CHUS/SERGAS), Travesía da Choupana s/n, 15706 Santiago de Compostela, Spain; eva.prida@rai.usc.es (E.P.); sara.fernandez.gonzalez@rai.usc.es (S.F.-G.); veronica.penaleon@gmail.com (V.P.-L.); raquel.perez.lois@rai.usc.es (R.P.-L.); luisamaria.seoane@usc.es (L.M.S.)

2 CIBER Fisiopatología de la Obesidad y Nutrición (CIBERobn), 15706 Santiago de Compostela, Spain

3 Hormone Laboratory, Department of Medical Biochemistry and Pharmacology, Haukeland University Hospital, N-5020 Bergen, Norway; johan.ferno@uib.no

4 Department of Physiology, CIMUS, University of Santiago de Compostela-Instituto de Investigación Sanitaria, 15782 Santiago de Compostela, Spain

* Correspondence: mar.quinones@usc.es (M.Q.); omar.al-massadi.iglesias@sergas.es (O.A.M.)

\section{check for}

Citation: Prida, E.; Fernández-

González, S.; Pena-León, V.;

Pérez-Lois, R.; Fernø, J.; Seoane, L.M.;

Quiñones, M.; Massadi, O.A.

Crosstalk between Melanin

Concentrating Hormone and

Endocrine Factors: Implications for

Obesity. Int. J. Mol. Sci. 2022, 23, 2436

https://doi.org/10.3390/ijms2305

2436

Academic Editor: Grażyna Nowicka

Received: 28 December 2021

Accepted: 21 February 2022

Published: 23 February 2022

Publisher's Note: MDPI stays neutral with regard to jurisdictional claims in published maps and institutional affiliations.

Copyright: (C) 2022 by the authors. Licensee MDPI, Basel, Switzerland. This article is an open access article distributed under the terms and conditions of the Creative Commons Attribution (CC BY) license (https:// creativecommons.org/licenses/by/ $4.0 /)$.

\begin{abstract}
Melanin-concentrating hormone $(\mathrm{MCH})$ is a 19aa cyclic peptide exclusively expressed in the lateral hypothalamic area, which is an area of the brain involved in a large number of physiological functions and vital processes such as nutrient sensing, food intake, sleep-wake arousal, memory formation, and reproduction. However, the role of the lateral hypothalamic area in metabolic regulation stands out as the most relevant function. $\mathrm{MCH}$ regulates energy balance and glucose homeostasis by controlling food intake and peripheral lipid metabolism, energy expenditure, locomotor activity and brown adipose tissue thermogenesis. However, the $\mathrm{MCH}$ control of energy balance is a complex mechanism that involves the interaction of several neuroendocrine systems. The aim of the present work is to describe the current knowledge of the crosstalk of $\mathrm{MCH}$ with different endocrine factors. We also provide our view about the possible use of melanin-concentrating hormone receptor antagonists for the treatment of metabolic complications. In light of the data provided here and based on its actions and function, we believe that the $\mathrm{MCH}$ system emerges as an important target for the treatment of obesity and its comorbidities.
\end{abstract}

Keywords: $\mathrm{MCH}$; hormones; energy balance; food intake; body weight; adiposity; type 2 diabetes; obesity

\section{Introduction}

\subsection{MCH: Precursor, Products, and Metabolic Actions}

Melanin-concentrating hormone (MCH) was first isolated in 1983 in the pituitary of chum salmon (Oncorhynchus keta), and its name comes from the ability of this hormone to control skin pigmentation [1-3]. Since its discovery, subsequent studies have determined that $\mathrm{MCH}$ is specifically expressed in the lateral hypothalamic area (LHA) and incertohypothalamic area of mammals, two important anatomic areas in the regulation of feeding behavior and energy conservation [4-6]. The gene encoding the pro-melaninconcentrating hormone (Pmch) generates a peptide of 165aa (pre-pro MCH) that is highly evolutionarily conserved and that, through different post-translational processes, gives rise to several products, of which $\mathrm{MCH}$ is the most metabolically relevant [4]. In rodents and humans, MCH comprises a 19aa peptide with a cysteine bridge [7], a molecular feature that gives $\mathrm{MCH}$ a cyclic structure essential for its biological activities [8]. The Pmch gene also yields other pro-MCH neuropeptides, such as neuropeptide-glutamic-isoleucine 
and neuropeptide-glycine-glutamic acid [4,9]. The function of these peptides remains elusive, but they seem to be devoid of metabolic effect [10-12]. MCH projections are widely distributed throughout the brain [4-6,13], suggesting that $\mathrm{MCH}$ could exert an array of biological functions. Indeed, $\mathrm{MCH}$ displays a well-characterized role in diverse physiologic processes, such as sleep [14], mood [15], and reproduction [16]. However, after the evidence presented in the mid-nineties that this peptide induces feeding [17], MCH rapidly came onto the scene as a pivotal player in the regulation of energy homeostasis. With regard to its metabolic functions, $\mathrm{MCH}$ induces an anabolic state/positive energy balance when centrally administered, by increasing food intake and the activation of peripheral lipid metabolism in the white adipose tissue (WAT) and in the liver [17-19]. In a similar manner, the over-expression of $\mathrm{MCH}$ in transgenic mice induces obesity by altering energy expenditure and locomotor activity [20]. Conversely, the pharmacological [21-23] and genetic (total or neuron-specific) inhibition of $\mathrm{MCH}[12,24-27]$ or melanin-concentrating hormone receptor 1 (MCH-R1) [28] leads to a negative energy balance. It is important to note that in pharmacological models, altered feeding behavior is the main cause of the metabolic actions of $\mathrm{MCH}$ signaling. However, in genetic mice models, the determining factor is often energy expenditure, as changes in feeding behavior are variable [2]. These divergent results could be due to regulatory changes in the genetic models caused during early development [29].

Interestingly $\mathrm{MCH}$ neurons also express other neurotransmitters, such as nesfatin or cocaine-and-amphetamine-regulated transcript [27,30,31]. Although the functions of these neuropeptides expressed by $\mathrm{MCH}$ neurons are poorly understood, they may act as mediators for the physiologic actions of these neurons [25,27,32]. In line with this, $\mathrm{MCH}$ neurons are mostly inhibitory and glutamatergic [13,32], although a subset was reported to be gamma aminobutyric acid (GABA)-ergic [32,33].

\subsection{MCH Regulation}

There are some preliminary reports demonstrating the presence of $\mathrm{MCH}$ in serum, but the source and functionality of the peripheral $\mathrm{MCH}$ immunoreactivity is still elusive $[34,35]$. However, consistent with its metabolic actions, $\mathrm{MCH}$ regulation changes with differences in nutritional status. Concretely, this neuropeptide is overexpressed after acute fasting [17], but not after long-term energy restriction [36]. MCH expression levels are increased in most models of obesity [37-39], suggesting that $\mathrm{MCH}$ may be involved in the etiology/pathogenesis of this disease. Interestingly, the $\mathrm{MCH}$ peptide content was significantly higher at the end of the sleeping period than at the end of the active period [40], suggesting that the level of the $\mathrm{MCH}$ peptide exhibits circadian variation. This result is in agreement with previous reports indicating that $\mathrm{MCH}$ levels in cerebrospinal fluid and neuronal $\mathrm{MCH}$ activity under normal or disturbed circadian rhythms patterns show a day/night difference [41-43]. However, other studies based on Pmch gene expression contradict these findings [44,45].

\section{MCH Receptors}

In 1999, MCH-R1 was characterized as the functional receptor by which MCH induces its actions. This was done by different research groups in parallel using reverse pharmacology as the main methodology [46-48]. The MCH-R1 is a seven-transmembrane domain G protein-coupled receptor that had previously been identified as an orphan receptor with the name of SLC-1/GPR24 [49]. In humans, the encoding gene is located in chromosome 22, q13.3. The peptide sequence comprises 353aa and is highly conserved in rats, mice, and humans (human-rat, 96\% identity; human-mouse, 95\% identity) [2]. MCH activates multiple intracellular signaling pathways, and these are associated with $\mathrm{G} \alpha \mathrm{i}, \mathrm{G} \alpha \mathrm{o}$, and $\mathrm{G} \alpha \mathrm{q} / 11$ proteins [50]. Activation of MCH-R1 transfected in mammalian cells leads to an increase in intracellular free $\mathrm{Ca}^{2+}$ by an increase in phospholipase $C \beta$ and an inhibition of forskolin-stimulated cyclic adenosine monophosphate [46]. Furthermore, MCH stimulates phosphoinositide metabolism and mitogen-activated protein kinase (MAPK) activity by 
both the $\mathrm{G} \alpha \mathrm{i}$ and $\mathrm{G} \alpha$ o proteins, but in an independent manner. Therefore, protein kinase $\mathrm{C}$ is essential for the stimulation of MAPK when this is dependent of G $\alpha$ o protein, but not when it depends on the G $\alpha$ i subunit [2,50].

The MCH-R1 is primarily expressed in the brain, but is also expressed in moderate levels in peripheral tissues, such the eyes or skeletal muscles, and to a lesser extent in the tongue and pituitary tissues [46]. In the brain, the highest expression of MCH-R1 is detected in the piriform cortex and the olfactory tubercle [51,52]. Strong expression was also detected in the hippocampal formation, the shell of the nucleus accumbens (NAc), and the amygdala [51,52], suggesting a role for $\mathrm{MCH}$ in olfactory learning and food reward, two important elements in the regulation of feeding [3]. In line with this, an expression of $\mathrm{MCH}-\mathrm{R} 1$ was found in the hypothalamus [51,52], the main homeostatic brain center that controls feeding and metabolic processes. This localization of the receptor indicates that $\mathrm{MCH}-\mathrm{R} 1$ may specifically mediate the effects of $\mathrm{MCH}$ on appetite and metabolism.

Another MCH-R of the 340-amino-acid was identified, called melanin concentrating hormone receptor 2 (MCH-R2) [53,54]. This receptor is located in chromosome 6 at band 6q16.2-16.3 and exhibits a 38\% homology with MCH-R1. Its expression is similar to that of $\mathrm{MCH}-\mathrm{R} 1$, but appears to be less abundant and to be expressed in less tissues than $\mathrm{MCH}-$ R1 [55]. MCH-R2 displays its highest expression in the brain frontal cortex, amygdala, and NAc $[53,54]$, but also in the peripheral tissues, including adipose, prostate, and intestine tissues [53]. The MCH-R2 only couples to the $\mathrm{G} \alpha \mathrm{q}$ protein subunit [54]. Interestingly this MCH-R2 is expressed only in certain mammals such as ferrets, dogs, or humans [56,57], but is not expressed in rodents [57], and its regulation in a gain-of-function mouse model showed opposite metabolic actions when compared to the MCH-R1 [13].

\section{Crosstalk of $\mathrm{MCH}$ and Endocrine Factors}

It is well known that the neuronal network in the hypothalamus may integrate peripheral information, such as nutrients and hormones, to modulate energy balance [58-60]. In line with this, some of the classical endocrine factors such as leptin, ghrelin, growth hormone $(\mathrm{GH})$, luteinizing hormone $(\mathrm{LH})$, cortisol or thyroid hormone $(\mathrm{TH})$ that are wellknown regulators of energy homeostasis, interact closely with $\mathrm{MCH}$ to exert different physiological functions. It is important to note that impairment of these signaling cascades could lead to obesity and related comorbidities, such as type 2 diabetes, non-alcoholic fatty liver disease, or some types of cancer [61,62]. Due to the rise in the prevalence of obesity, it has become a major social, economic, and health problem [63-65]; therefore, it is important to preserve the proper functionality of the endocrine physiology to avoid any metabolic complications.

\subsection{MCH and Insulin}

There is a variety experimental evidence showing an interaction between $\mathrm{MCH}$ and insulin. For example, a peripheral administration of insulin produces an increase in the expression of mRNA and protein levels of $\mathrm{MCH}$ [66], as well as an increase in the excitability of the MCH neurons [67] (Figure 1: pp 6). Likewise, it has been shown that insulin signaling in $\mathrm{MCH}$ neurons is dispensable for energy and glucose homeostasis in mice fed a standard diet. However, mice deficient for the insulin receptor (IR), specifically in the MCH neurons (IRDMCH), have a greater sensitivity to insulin compared to control mice when fed a high-fat diet (HFD) [67]. These IRDMCH mice had lower glucose production in the liver, while the uptake of glucose in WAT or brown adipose tissue (BAT) is not affected, indicating that the alteration of insulin signaling in the $\mathrm{MCH}$ neurons of obese mice improves their ability to suppress the production of hepatic glucose, producing a greater sensitivity to insulin [67]. 


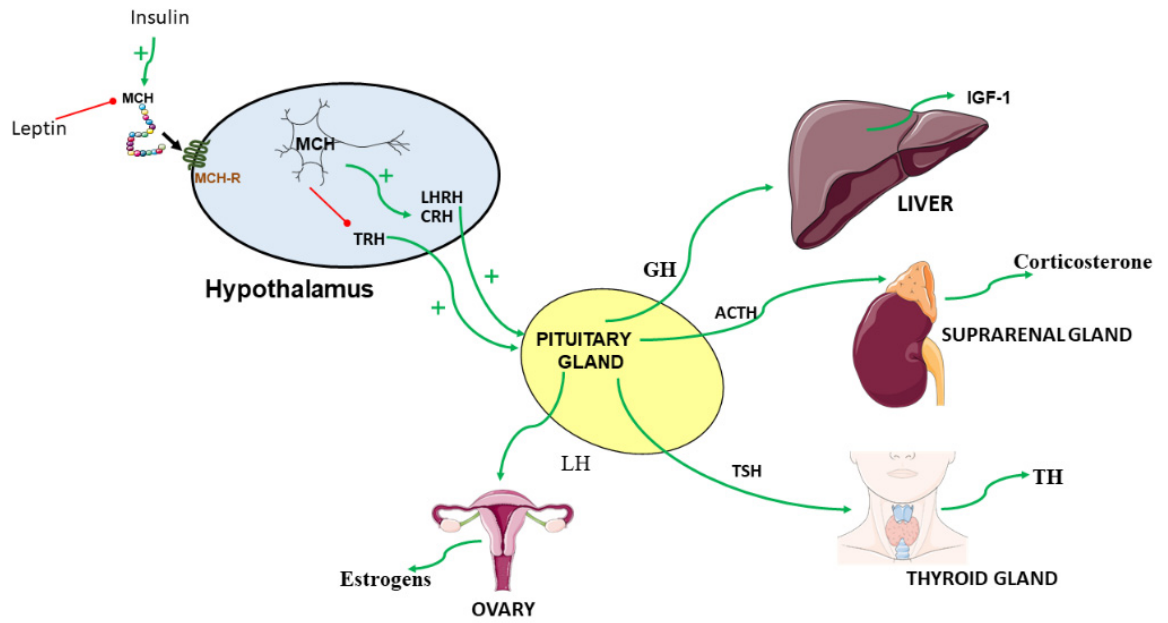

Figure 1. A description of the crosstalk between the $\mathrm{MCH}$ and endocrine factors. Abbreviations used: ACTH—adrenocorticotropic hormone; $\mathrm{CRH}$-corticotrophin-releasing factor; $\mathrm{GH}$-growth hormone; IGF-1—insulin growth factor 1; LH-luteinizing hormone; LHRH-luteinizing hormone releasing hormone; $\mathrm{MCH}$-melanin concentrating hormone; $\mathrm{MCH}-\mathrm{R}$-melanin-concentrating hormone receptor; $\mathrm{TH}$ - Thyroid hormone; $\mathrm{TRH}$ — thyroid releasing hormone; $\mathrm{TSH}$-thyroid stimulating hormone. The figures were generated by using materials from Servier Medical Art (Servier) under consideration of a Creative Commons Attribution 3.0 Unported License.

\section{2. $\mathrm{MCH}$ and Leptin}

Like insulin, leptin also modulates the activity of the MCH system [68] (Figure 1). $\mathrm{MCH}$ expression increases in obese leptin-null (ob/ob) mice, suggesting a close interplay between $\mathrm{MCH}$ and leptin activity. In line with this, obese rats with a point mutation in the long form of the leptin receptor, the Zucker LepR fa/fa rats, exhibit an upregulation of $\mathrm{MCH}$ expression and a downregulation of $\mathrm{MCH}-\mathrm{R} 1$ levels in comparison with lean rats [38]. At the same time, the fasting-dependent decrease in serum leptin induces an increase in the circulating $\mathrm{MCH}$ levels that, in turn, are counter-regulated by the administration of human recombinant leptin [69]. If we take these data together, we can deduce that the lack of leptin is associated with an increase in the hypothalamic expression of $\mathrm{MCH}$, which is consistent considering that $\mathrm{MCH}$ stimulates food intake and promotes an increase in body weight [3]. Nevertheless, $\mathrm{MCH}$ transgenic mice are hyperleptinemic [20], and neural $\mathrm{MCH}$ knockout $(\mathrm{KO})$ mice display hypoleptinemia. However, the leptin response on appetite in these mice is normal [25].

In agreement with these data, when deleting MCH-R1 in ob/ob mice, a phenotype characterized by greater lean mass, lower body fat and greater locomotor activity is achieved compared to ob/ob mice that present intact MCH-R1 [70]. However, the congenital disruption of the $\mathrm{MCH}$ peptide or the loss of $\mathrm{MCH}$ neurons in ob/ob mice leads to an improvement of the obese phenotype [25,71]. Of note, this did not occur when the disruption of the $\mathrm{MCH}$ system was performed in adulthood [72], where the loss of $\mathrm{MCH}$ only induces an improvement in glucose homeostasis. Therefore, these double congenital $\mathrm{KO}$ mice are hypophagic, lean, and show low glucose levels compared to ob/ob mice. However, the reversal of obesity is not complete, indicating that other pathways are involved in the response to chronic leptin deficiency. The greater amount of lean mass and the lower level of fat in the MCH-R1-deficient ob/ob mice could be explained as a consequence of the increased locomotor activity, which in turn would explain the greater sensitivity to insulin. All of these results suggest an important role of $\mathrm{MCH}$ in mediating the physiological response of chronic leptin deficiency. 


\section{3. $\mathrm{MCH}$ and Somatotropic Function}

$\mathrm{MCH}$ and the gastric hormone ghrelin take part in the regulation of energy homeostasis, and both stimulate food intake [17,58]. Ghrelin administration or ghrelin depletion by a surgical intervention does not regulate the $\mathrm{MCH}$ mRNA expression in the hypothalamus [73]. Consistent with this, the orexigenic action of ghrelin is independent of $\mathrm{MCH}$ signaling since ghrelin is able to induce food intake in MCH-R KO mice [74]. However, $\mathrm{MCH}$ signaling seems to play a role for other ghrelin actions, such as the induction of $\mathrm{GH}$ secretion $[74,75]$. Thus, GH mRNA levels were markedly increased in response to ghrelin injection in the wild-type (WT) mice, but were blunted in the MCH-R KO mice [74]. In line with this, it has been reported that MCH-R1 is expressed in the pituitary gland of rodents and humans [46,76], and that $\mathrm{MCH}$ neurons project to the median eminence region of the brain $[5,77]$. These data indicate that the $\mathrm{MCH}$ system affects pituitary function. The functional characterization of this interaction was determined by studies showing that $\mathrm{MCH}$ increased GH-secretion in human and rodent pituitary cells [75]. Furthermore, chronic in vivo $\mathrm{MCH}$ administration results in an increase in plasma insulin growth factor 1 (IGF-1) levels [78]. Meanwhile, MCH-R KO mice had significantly lower serum IGF-1 levels than the WT mice [74]. Finally, since IGF-1 is released mainly by the liver and, together with GH, induces changes in body weight and body composition, we can conclude that $\mathrm{MCH}$ may exert some of its effects on energy balance, at least in part, via regulation of the GH-IGF axis or somatotropic function (Figure 1).

\section{4. $\mathrm{MCH}$ and Hypothalamic-Pituitary Gonadal Axis}

Food restriction upregulates the $\mathrm{MCH}$ expression [17], and in turn, this hormone decreases energy expenditure and increases food intake [3]. In concordance, as we pointed out earlier, pharmacological or genetic MCH inhibition in mice has opposite effects, displaying a negative energy balance. Starvation has negative consequences on fertility because decreased circulating gonadotropins induces anovulation [79]. However, despite these effects, $\mathrm{MCH}$ [24] and MCH-R1 null mice [28] remain fertile. These data suggest that $\mathrm{MCH}$ could play a role in reproduction. In line with this, $\mathrm{MCH}$ fibers are in close apposition with the hypothalamic gonadotropin releasing hormone $(\mathrm{GnRH})$ neurons, and $50-55 \%$ of rat $\mathrm{GnRH}$ neurons express MCH-R1 [80]. Thus, $\mathrm{MCH}$ may target $\mathrm{GnRH}$ neurons in the hypothalamus. Interestingly, $\mathrm{MCH}$ stimulates the release of luteinizing hormone-releasing hormone [Figure 1] and gonadotropins in vitro, acting at both median eminence (ME) and pituitary levels [81]. Moreover, when administered into the ME and medial pre-optic area (MPOA), $\mathrm{MCH}$ stimulates the release of luteinizing hormone $(\mathrm{LH})$ in vivo as well $[82,83]$. In contrast, the administration of anti-MCH antiserum in the MPOA inhibits LH release [82]. Another approach using estradiol benzoate on ovariectomized rats confirms these results and indeed demonstrates that the effects of $\mathrm{MCH}$ on fertility are mediated by the melanocortin system. In this model, the effect of MCH on LH was blocked by the administration of the melanocortin 4/5 (MC4/5) antagonist and the melanocortin 3/5 (MC3/5) antagonist, but not by the melanocortin 3/4 (MC3/4) antagonist, into the MPOA [83].

In contrast, leptin, an anorexigenic hormone secreted by adipose tissue, also influences sexual maturation and fertility [84]. Both $\mathrm{MCH}$ and leptin stimulate sexual behavior, and it has been shown that the effect of leptin on LH release is mediated by $\mathrm{MCH}$ [83]. Thus, an administration of an $\mathrm{MCH}$ antiserum into the MPOA prevented the surge in LH induced by leptin when this hormone was injected into the zona incerta [83]. In addition, MC3/5 and $\mathrm{MC} 4 / 5$, previously shown to inhibit the stimulatory effect of $\mathrm{MCH}$ on $\mathrm{LH}$ release, also inhibited the effect of leptin [83]. These data suggest that $\mathrm{MCH}$ per se plays a relevant role in fertility, and that its activity is necessary for other hormones, such as leptin, to promote reproductive activity.

\section{Role of Estrogens}

Estrogens constitute a group of sex hormones derived from cholesterol (steroids) that are mainly produced in the ovaries, adrenal glands, and the placenta in pregnant women. 
It should be noted that estrogens are also present in low concentrations in men. Their synthesis is stimulated by the release of follicle-stimulating hormone ( $\mathrm{FSH})$, a hormone that regulates $\mathrm{GnRH}$ and that is subject to regulation by estrogens via a negative feedback loop. Estrogen levels in females vary cyclically and generally reduce food intake [85].

It has been shown that the orexigenic effect of $\mathrm{MCH}$ is sexually dimorphic and that estrogen is the potent responsible anorexigenic signal [86-88]. This affirmation is based on experiments in rats submitted to ovariectomy (OVX) and estrogen replacement. Thus, OVX rats with estrogen replacement are less sensitive to the orexigenic action of $\mathrm{MCH}$ compared to OVX controls and male rats $[16,87,88]$. Moreover, the food intake induced by $\mathrm{MCH}$ is clearly compromised in female rats on the estrus cycle compared to the control rats on the diestrus cycle [16]. These studies demonstrate the deleterious effect of estrogen on the $\mathrm{MCH}$ control of feeding and hence could explain one of the mechanisms by which the loss of estrogen in aged women induces an increase in body weight and adiposity.

\subsection{MCH Hypothalamo-Pituitary Thyroid Axis}

The thyroid axis is an important regulator of energy homeostasis, specifically with regard to the control of food intake and energy expenditure [89,90]. Fasting leads to a profound suppression of the thyroid stimulating hormone (TSH) in the pituitary, thyroid releasing hormone (TRH) in the paraventricular nucleus (PVN), as well as circulating thyroxine [91]. Due to the well-known effects of calorie restriction on $\mathrm{MCH}$ and the fact that MCH-R1 is expressed in thyroid follicular cells, an interaction between these endocrine systems is plausible. In this sense, mice lacking MCH-R1 exhibit reduced secretion of the circulating inactive form of thyroid hormone $(\mathrm{TH})$, namely the free and total tetraiodothyronine and the active form of $\mathrm{TH}$ or liothyronine. At the same time, these mice display high levels of TRH and TSH when compared with WT mice [28,92]. Moreover, when $\mathrm{MCH}$ is administered intracerebroventricularly, plasma TSH in vivo and the release of TRH from hypothalamic explants are significantly reduced [93] (Figure 1). Furthermore, $\mathrm{MCH}$ was also shown to significantly reduce the TRH-stimulated TSH release from pituitary cell cultures [93]. These data suggest a possible role of $\mathrm{MCH}$ in the control of energy homeostasis via the inhibition of the thyroid axis. Specifically, these data could explain the mechanism responsible for the decreased energy expenditure after $\mathrm{MCH}$ injection.

\section{6. $\mathrm{MCH}$ and Hypothalamic-Pituitary Adrenal Axis}

The hypothalamic pituitary adrenal (HPA) axis is a neuroendocrine pathway that is activated by stress and comprised of three endocrine components: (1) the corticotrophinreleasing factor $(\mathrm{CRH})$ that resides within the PVN, (2) adrenocorticotropic hormone (ACTH) that is released from the anterior pituitary, and (3) cortisol and corticosterone which are the main glucocorticoids secreted by human and rodent adrenal glands, respectively [94]. The direct administration of $\mathrm{MCH}$ to hypothalamic explants stimulates the release of $\mathrm{CRH}$ (Figure 1), an effect that is blocked by the administration of the MCH-R1 antagonist. In vivo, a specific injection of $\mathrm{MCH}$ into the PVN increases circulating serum levels of ACTH and corticosterone [95-97]. However, $\mathrm{MCH}$ reduces corticosterone levels in rats after exposure to stress [97]. Moreover, $\mathrm{MCH}$ has an anxiogenic-like effects when it is administered centrally, in agreement with the elevated $\mathrm{MCH}$ levels observed after being subjected to the elevated plus maze or the forced swim test, two standard test to measure the anxiety/stress response in rodents $[97,98]$. In contrast, MCH-R1 antagonist exhibits opposite effects and attenuates the anxiogenic and prodepressant activity in rodents [97,98]. This interesting effect of $\mathrm{MCH}$ on stress and depression provides an advantage for the development of a therapeutic option targeting MCH signaling.

\section{Conclusions and Remarks}

The prevalence of obesity is rising, reaching pandemic proportions in both developed and developing countries. Obesity may lead to comorbidities such as type 2 diabetes, cardiovascular disease, and liver disease, making it is a complex and multifactorial illness 
involving genetic, biological and behavioral factors. Substantial progress has been made in the last few decades in understanding the molecular pathways and physiological systems governing energy balance. While several anti-obesity drugs have been approved by the Food and Drug Administration and/or the European Medicines Agency, their efficacy and/or safety is still a concern. Currently, the most effective and sustainable approach to decrease body weight and to improve glucose metabolism is bariatric surgery; however, its invasiveness and side effects limits the access of this approach to obese patients in the general population. Because of this, the elucidation of new therapies that could help to slow, prevent, or revert the obesity epidemic are urgently needed. In this sense $\mathrm{MCH}$, due to its actions on food intake, adiposity, energy expenditure, and food motivation, has attracted the attention of several pharmaceutical companies as a possible target for the development of anti-obesity drugs. As we pointed out previously, $\mathrm{MCH}$, in addition to increased feeding, regulates glucose homeostasis and insulin sensitivity, suggesting its potential as a target for the combined treatment for both obesity and type 2 diabetes. Furthermore, MCH expression levels are increased in several obese models, such as agouti mice, leptin and leptin receptor deficient mice, and Zucker rats, suggesting that $\mathrm{MCH}$ may be involved in the etiology/pathogenesis of this disease. Importantly, an MCH-R1 antagonist could be effective in pathological states associated with age, such as estrogen deficiency that occurs in women after menopause, or in improving leptin sensitivity in states associated with leptin resistance.

It is important to note that the development of compounds based on MCH-R1 ligands present some advantages compared to other potential drugs. Using MCH-R1 antagonists in preclinical animal models has shown efficacy against anxiety and depression due to the effects on the adrenal axis. This is contrary to other compounds, such as rimonabant or lorcaserin that were withdrawn from the market for their off-target consequences leading to psychological side effects. Despite the promising data obtained from preclinical animal models, only six MCH-R1 antagonists underwent clinical trials. Unfortunately, all of them were stopped in phase I clinical trials for several reasons, including low safety, low bioavailability, or lack of efficacy. Therefore, these features should be improved with the next generation of compounds, as we believe that MCH-R1 is still a promising target for the treatment of metabolic diseases. In this sense, other drugs based on $\mathrm{MCH}$ signaling with the intent to treat metabolic derangements other than obesity should be explored. Candidates for treatment could be anorexia or liver disease, for which this peptide was found to have therapeutic potential. Furthermore, due to the high orexigenic and adipogenic action of $\mathrm{MCH}$, the therapeutic use of $\mathrm{MCH}$ agonist should be considered in the treatment of other diseases characterized by the chronic loss of lean or fat mass, such as sarcopenia or cachexia.

Importantly, increasing the knowledge of the interaction of $\mathrm{MCH}$ with other hormones can help to design more effective antagonists, as well as avoid adverse side effects. Besides this, it could be relevant to combine contemporary therapies intended to target various targets at once in combinatory therapy or unimolecular polypharmacy. Moreover, due to the neuron-specific action of $\mathrm{MCH}$ on metabolic processes such as peripheral lipid deposition, induction of glucose intolerance, or feeding, the use of novel technologies that target specific neuron populations in the brain could provide new avenues in the development of $\mathrm{MCH}$ based therapies for treating metabolic diseases. In this sense, the direct inhibition of $\mathrm{MCH}$ at the neuronal level instead of the broad pharmacological inhibition of MCH-R1 seems a more plausible and effective therapeutic method due to its specificity. However, this strategy is still elusive and will require development of new targeted molecules or delivery methods.

Overall, after studying the relationship of $\mathrm{MCH}$ to other endocrine factors and how they influence metabolic control as a whole, we believe that the study of this hormone, as well as pharmacological exploration of its potential as a drug, is of utmost importance to allow us to tackle obesity and its related complications. 


\begin{abstract}
Author Contributions: M.Q. and O.A.M. wrote the manuscript. All authors made substantial contributions to the discussion of the content and reviewed/edited the manuscript before submission. All authors have read and agreed to the published version of the manuscript.

Funding: This research was funded by the Instituto de Salud Carlos III-European Union grant number PI21/01216 (O.A.M.), Fundación de la Sociedad Gallega de Endocrinología y Nutrición (O.A.M.); and Ministerio de Ciencia e Innovación PID2020-114350RJ-I00 (M.Q.). Centro de Investigación Biomédica en Red (CIBER) de Fisiopatología de la Obesidad y Nutrición (CIBERobn). CIBERobn is an initiative of the Instituto de Salud Carlos III (ISCIII) of Spain, which is supported by FEDER funds; Western Norway Regional Health Authority (Helse Vest RHF). M.Q. is a recipient of a JIN-RETOS contract from Ministerio de Ciencia e Innovación (PID2020-114350RJ-I00). O.A.M. was funded by a research contract Miguel Servet (CP20/00146) from the ISCIII. The data figures were generated by using materials from Servier Medical Art (Servier) under consideration of a Creative Commons Attribution 3.0 Unported License.
\end{abstract}

Institutional Review Board Statement: Not applicable.

Informed Consent Statement: Not applicable.

Data Availability Statement: Not applicable.

Conflicts of Interest: The authors declare no conflict of interest.

\title{
References
}

1. Kawauchi, H.; Kawazoe, I.; Tsubokawa, M.; Kishida, M.; Baker, B.I. Characterization of melanin-concentrating hormone in chum salmon pituitaries. Nature 1983, 305, 321-323. [CrossRef] [PubMed]

2. Pissios, P.; Bradley, R.L.; Maratos-Flier, E. Expanding the scales: The multiple roles of MCH in regulating energy balance and other biological functions. Endocr. Rev. 2006, 27, 606-620. [CrossRef] [PubMed]

3. Al-Massadi, O.; Dieguez, C.; Schneeberger, M.; Lopez, M.; Schwaninger, M.; Prevot, V.; Nogueiras, R. Multifaceted actions of melanin-concentrating hormone on mammalian energy homeostasis. Nat. Rev. Endocrinol. 2021, 17, 745-755. [CrossRef] [PubMed]

4. Nahon, J.L.; Presse, F.; Bittencourt, J.C.; Sawchenko, P.E.; Vale, W. The rat melanin-concentrating hormone messenger ribonucleic acid encodes multiple putative neuropeptides coexpressed in the dorsolateral hypothalamus. Endocrinology 1989, 125, $2056-2065$. [CrossRef] [PubMed]

5. $\quad$ Bittencourt, J.C.; Presse, F.; Arias, C.; Peto, C.; Vaughan, J.; Nahon, J.L.; Vale, W.; Sawchenko, P.E. The melanin-concentrating hormone system of the rat brain: An immuno- and hybridization histochemical characterization. J. Comp. Neurol. 1992, 319, 218-245. [CrossRef]

6. Bittencourt, J.C. Anatomical organization of the melanin-concentrating hormone peptide family in the mammalianbrain. Gen. Comp. Endocrinol. 2011, 172, 185-197. [CrossRef] [PubMed]

7. Vaughan, J.M.; Fischer, W.H.; Hoeger, C.; Rivier, J.; Vale, W. Characterization of melanin-concentrating hormone from rat hypothalamus. Endocrinology 1989, 125, 1660-1665. [CrossRef]

8. Matsunaga, T.O.; Hruby, V.J.; Lebl, M.; Castrucci, A.M.; Hadley, M.E. Synthesis and bioactivity studies of two isosteric acyclic analogues of melanin concentrating hormone. Life Sci. 1992, 51, 679-685. [CrossRef]

9. Parkes, D.; Vale, W. Secretion of melanin-concentrating hormone and neuropeptide-EI from cultured rat hypothalamic cells. Endocrinology 1992, 131, 1826-1831. [CrossRef]

10. Mul, J.D.; La Fleur, S.E.; Toonen, P.W.; Afrasiab-Middelman, A.; Binnekade, R.; Schetters, D.; Verheij, M.M.M.; Sears, R.M.; Homberg, J.R.; Schoffelmeer, A.N.M.; et al. Chronic loss of melanin-concentrating hormone affects motivational aspects of feeding in the rat. PLoS ONE 2011, 6, e19600. [CrossRef]

11. Rossi, M.; Choi, S.J.; O'Shea, D.; Miyoshi, T.; Ghatei, M.A.; Bloom, S.R. Melanin-concentrating hormone acutely stimulates feeding, but chronic administration has no effect on body weight. Endocrinology 1997, 138, 351-355. [CrossRef] [PubMed]

12. Jeon, J.Y.; Bradley, R.L.; Kokkotou, E.G.; Marino, F.E.; Wang, X.; Pissios, P.; Maratos-Flier, E. MCH-/- mice are resistant to aging-associated increases in body weight and insulin resistance. Diabetes 2006, 55, 428-434. [CrossRef] [PubMed]

13. Chee, M.J.; Pissios, P.; Maratos-Flier, E. Neurochemical characterization of neurons expressing melanin-concentrating hormone receptor 1 in the mouse hypothalamus. J. Comp. Neurol. 2013, 521, 2208-2234. [CrossRef]

14. Izawa, S.; Chowdhury, S.; Miyazaki, T.; Mukai, Y.; Ono, D.; Inoue, R.; Ohmura, Y.; Mizoguchi, H.; Kimura, K.; Yoshioka, M.; et al. REM sleep-active MCH neurons are involved in forgetting hippocampus-dependent memories. Science 2019, 365, 1308-1313. [CrossRef] [PubMed]

15. Borowsky, B.; Durkin, M.M.; Ogozalek, K.L.; Marzabadi, M.R.; Deleon, J.E.; Heurich, R.O.; Lichtblau, H.; Shaposhnik, Z.; Daniewska, I.; Blackburn, T.P.; et al. Antidepressant, anxiolytic and anorectic effects of a melanin-concentrating hormone-1 receptor antagonist. Nat. Med. 2002, 8, 825-830. [CrossRef] [PubMed]

16. Santollo, J.; Eckel, L.A. The orexigenic effect of melanin-concentrating hormone (MCH) is influenced by sex and stage of the estrous cycle. Physiol. Behav. 2008, 93, 842-850. [CrossRef] [PubMed] 
17. Qu, D.; Ludwig, D.; Gammeltoft, S.; Piper, M.E.; Pelleymounter, M.A.; Cullen, M.J.; Mathes, W.F.; Przypek, J.; Kanarek, R.B.; Maratos-Flier, E. A role for melanin-concentrating hormone in the central regulation of feeding behaviour. Nature 1996, 380, 243-247. [CrossRef]

18. Gomori, A.; Ishihara, A.; Ito, M.; Mashiko, S.; Matsushita, H.; Yumoto, M.; Ito, M.; Tanaka, T.; Tokita, S.; Moriya, M.; et al. Chronic intracerebroventricular infusion of $\mathrm{MCH}$ causes obesity in mice. Melanin-concentrating hormone. Am. J. Physiol. Endocrinol. Metab. 2003, 284, E583-E588. [CrossRef]

19. Imbernon, M.; Beiroa, D.; Vázquez, M.J.; Morgan, D.A.; Veyrat-Durebex, C.; Porteiro, B.; Díaz-Arteaga, A.; Senra, A.; Busquets, S.; Velásquez, D.A.; et al. Central melanin-concentrating hormone influences liver and adipose metabolism via specific hypothalamic nuclei and efferent autonomic/JNK1 pathways. Gastroenterology 2013, 144, 636-649.e6. [CrossRef]

20. Ludwig, D.S.; Tritos, N.A.; Mastaitis, J.W.; Kulkarni, R.; Kokkotou, E.; Elmquist, J.; Lowell, B.; Flier, J.S.; Maratos-Flier, E. Melanin-concentrating hormone overexpression in transgenic mice leads to obesity and insulin resistance. J. Clin. Investig. 2001, 107, 379-386. [CrossRef]

21. Ito, M.; Ishihara, A.; Gomori, A.; Egashira, S.; Matsushita, H.; Mashiko, S.; Ito, J.; Ito, M.; Nakase, K.; Haga, Y.; et al. Melaninconcentrating hormone 1-receptor antagonist suppresses body weight gain correlated with high receptor occupancy levels in diet-induced obesity mice. Eur. J. Pharm. 2009, 624, 77-83. [CrossRef] [PubMed]

22. Mashiko, S.; Ishihara, A.; Gomori, A.; Moriya, R.; Ito, M.; Iwaasa, H.; Matsuda, M.; Feng, Y.; Shen, Z.; Marsh, D.J.; et al. Antiobesity effect of a melanin-concentrating hormone 1 receptor antagonist in diet-induced obese mice. Endocrinology 2005, 146, 3080-3086. [CrossRef] [PubMed]

23. Shearman, L.P.; Camacho, R.E.; Stribling, D.S.; Zhou, D.; Bednarek, M.A.; Hreniuk, D.L.; Feighner, S.D.; Tan, C.P.; Howard, A.D.; Van der Ploeg, L.H.; et al. Chronic MCH-1 receptor modulation alters appetite, body weight and adiposity in rats. Eur. J. Pharm. 2003, 475, 37-47. [CrossRef]

24. Shimada, M.; Tritos, N.A.; Lowell, B.B.; Flier, J.S.; Maratos-Flier, E. Mice lacking melanin-concentrating hormone are hypophagic and lean. Nature 1998, 396, 670-674. [CrossRef]

25. Alon, T.; Friedman, J.M. Late-onset leanness in mice with targeted ablation of melanin concentrating hormone neurons. J. Neurosci. 2006, 26, 389-397. [CrossRef]

26. Wang, Y.; Ziogas, D.C.; Biddinger, S.; Kokkotou, E. You deserve what you eat: Lessons learned from the study of the melaninconcentrating hormone (MCH)-deficient mice. Gut 2010, 59, 1625-1634. [CrossRef] [PubMed]

27. Whiddon, B.B.; Palmiter, R.D. Ablation of neurons expressing melanin-concentrating hormone (MCH) in adult mice improves glucose tolerance independent of MCH signaling. J. Neurosci. 2013, 33, 2009-2016. [CrossRef] [PubMed]

28. Marsh, D.J.; Weingarth, D.T.; Novi, D.E.; Chen, H.Y.; Trumbauer, M.E.; Chen, A.S.; Guan, X.-M.; Jiang, M.M.; Feng, Y.; Camacho, R.E.; et al. Melanin-concentrating hormone 1 receptor-deficient mice are lean, hyperactive, and hyperphagic and have altered metabolism. Proc. Natl. Acad. Sci. USA 2002, 99, 3240-3245. [CrossRef]

29. Szalai, K.K.; Beke, G.; Eles, J.; Kitka, T.; Kovacs, P.; Nagy, J.; Farkas, S.; Boros, A. Recent patents on novel MCH1 receptor antagonists as potential anti-obesity drugs. Recent. Pat. CNS Drug Discov. 2014, 9, 122-140. [CrossRef] [PubMed]

30. Elias, C.F.; Lee, C.E.; Kelly, J.F.; Ahima, R.S.; Kuhar, M.; Saper, C.B.; Elmquist, J.K. Characterization of CART neurons in the rat and human hypothalamus. J. Comp. Neurol. 2001, 432, 442-459. [CrossRef]

31. Fort, P.; Salvert, D.; Hanriot, L.; Jego, S.; Shimizu, H.; Hashimoto, K.; Mori, M.; Luppi, P.H. The satiety molecule nesfatin-1 is co-expressed with melanin concentrating hormone in tuberal hypothalamic neurons of the rat. Neuroscience 2008, 155, 174-181. [CrossRef] [PubMed]

32. Schneeberger, M.; Tan, K.; Nectow, A.R.; Parolari, L.; Caglar, C.; Azevedo, E.; Li, Z.; Domingos, A.; Friedman, J.M. Functional analysis reveals differential effects of glutamate and MCH neuropeptide in MCH neurons. Mol. Metab. 2018, 13, 83-89. [CrossRef] [PubMed]

33. Nieh, E.H.; Vander Weele, C.M.; Matthews, G.A.; Presbrey, K.N.; Wichmann, R.; Leppla, C.A.; Izadmehr, E.M.; Tye, K.M. Inhibitory Input from the Lateral Hypothalamus to the Ventral Tegmental Area Disinhibits Dopamine Neurons and Promotes Behavioral Activation. Neuron 2016, 90, 1286-1298. [CrossRef] [PubMed]

34. Naufahu, J.; Alzaid, F.; Fiuza Brito, M.; Doslikova, B.; Valencia, T.; Cunliffe, A.; Murray, J.F. Melanin-concentrating hormone in peripheral circulation in the human. J. Endocrinol. 2017, 232, 513-523. [CrossRef]

35. Carnier, J.; de Piano, A.; Sanches, P.D.L.; Tock, L.; Nascimento, C.M.O.D.; Oyama, L.M.; Corrêa, F.A.; Ernandes, R.H.; Lederman, H.; de Mello, M.T.; et al. The role of orexigenic and anorexigenic factors in an interdisciplinary weight loss therapy for obese adolescents with symptoms of eating disorders. Int. J. Clin. Pract. 2010, 64, 784-790. [CrossRef]

36. Mequinion, M.; Le Thuc, O.; Zgheib, S.; Alexandre, D.; Chartrel, N.; Rovere, C.; Hardouin, P.; Viltart, O.; Chauveau, C. Long-Term Energy Deficit in Mice Causes Long-Lasting Hypothalamic Alterations after Recovery. Neuroendocrinology 2017, 105, 372-383. [CrossRef]

37. Hanada, R.; Nakazato, M.; Matsukura, S.; Murakami, N.; Yoshimatsu, H.; Sakata, T. Differential regulation of melaninconcentrating hormone and orexin genes in the agouti-related protein/melanocortin-4 receptor system. Biochem. Biophys. Res. Commun. 2000, 268, 88-91. [CrossRef]

38. Stricker-Krongrad, A.; Dimitrov, T.; Beck, B. Central and peripheral dysregulation of melanin-concentrating hormone in obese Zucker rats. Brain Res. Mol. Brain Res. 2001, 92, 43-48. [CrossRef] 
39. Mizuno, T.M.; Kleopoulos, S.P.; Bergen, H.T.; Roberts, J.L.; Priest, C.A.; Mobbs, C.V. Hypothalamic pro-opiomelanocortin mRNA is reduced by fasting and [corrected] in ob/ob and db/db mice, but is stimulated by leptin. Diabetes 1998, 47, 294-297. [CrossRef]

40. Gerics, B.; Szalay, F.; Sotonyi, P.; Jancsik, V. Diurnal variation of the melanin-concentrating hormone level in the hypothalamus. Acta Biol. Hung. 2017, 68, 14-21. [CrossRef]

41. Ramirez-Plascencia, O.D.; Saderi, N.; Escobar, C.; Salgado-Delgado, R.C. Feeding during the rest phase promotes circadian conflict in nuclei that control energy homeostasis and sleep-wake cycle in rats. Eur. J. Neurosci. 2017, 45, 1325-1332. [CrossRef] [PubMed]

42. Dias Abdo Agamme, A.L.; Aguilar Calegare, B.F.; Fernandes, L.; Costa, A.; Lagos, P.; Torterolo, P.; D'Almeida, V. MCH levels in the CSF, brain preproMCH and MCHR1 gene expression during paradoxical sleep deprivation, sleep rebound and chronic sleep restriction. Peptides 2015, 74, 9-15. [CrossRef] [PubMed]

43. Pelluru, D.; Konadhode, R.; Shiromani, P.J. MCH neurons are the primary sleep-promoting group. Sleep 2013, 36, 1779-1781. [CrossRef] [PubMed]

44. Stutz, A.M.; Staszkiewicz, J.; Ptitsyn, A.; Argyropoulos, G. Circadian expression of genes regulating food intake. Obesity 2007, 15, 607-615. [CrossRef] [PubMed]

45. Harthoorn, L.F.; Sane, A.; Nethe, M.; Van Heerikhuize, J.J. Multi-transcriptional profiling of melanin-concentrating hormone and orexin-containing neurons. Cell Mol. Neurobiol. 2005, 25, 1209-1223. [CrossRef] [PubMed]

46. Saito, Y.; Nothacker, H.P.; Wang, Z.; Lin, S.H.; Leslie, F.; Civelli, O. Molecular characterization of the melanin-concentratinghormone receptor. Nature 1999, 400, 265-269. [CrossRef]

47. Chambers, J.; Ames, R.S.; Bergsma, D.; Muir, A.I.; Fitzgerald, L.R.; Hervieu, G.; Dytko, G.M.; Foley, J.J.; Martin, J.F.; Liu, W.-S.; et al. Melanin-concentrating hormone is the cognate ligand for the orphan G-protein-coupled receptor SLC-1. Nature 1999, 400, 261-265. [CrossRef]

48. Lembo, P.M.; Grazzini, E.; Cao, J.; Hubatsch, D.A.; Pelletier, M.; Hoffert, C.; St-Onge, S.; Pou, C.; Labrecque, J.; Groblewski, T.; et al. The receptor for the orexigenic peptide melanin-concentrating hormone is a G-protein-coupled receptor. Nat. Cell Biol. 1999, 1, 267-271. [CrossRef]

49. Kolakowski, L.F., Jr.; Jung, B.P.; Nguyen, T.; Johnson, M.P.; Lynch, K.R.; Cheng, R.; Heng, H.H.; George, S.R.; O’Dowd, B.F. Characterization of a human gene related to genes encoding somatostatin receptors. FEBS Lett. 1996, 398, 253-258. [CrossRef]

50. Hawes, B.E.; Kil, E.; Green, B.; O'Neill, K.; Fried, S.; Graziano, M.P. The melanin-concentrating hormone receptor couples to multiple $G$ proteins to activate diverse intracellular signaling pathways. Endocrinology 2000, 141, 4524-4532. [CrossRef]

51. Hervieu, G.J.; Cluderay, J.E.; Harrison, D.; Meakin, J.; Maycox, P.; Nasir, S.; Leslie, R.A. The distribution of the mRNA and protein products of the melanin-concentrating hormone $(\mathrm{MCH})$ receptor gene, slc-1, in the central nervous system of the rat. Eur. J. Neurosci. 2000, 12, 1194-1216. [CrossRef] [PubMed]

52. Saito, Y.; Cheng, M.; Leslie, F.M.; Civelli, O. Expression of the melanin-concentrating hormone (MCH) receptor mRNA in the rat brain. J. Comp. Neurol. 2001, 435, 26-40. [CrossRef] [PubMed]

53. Hill, J.; Duckworth, M.; Murdock, P.; Rennie, G.; Sabido-David, C.; Ames, R.S.; Szekeres, P.; Wilson, S.; Bergsma, D.J.; Gloger, I.S.; et al. Molecular cloning and functional characterization of $\mathrm{MCH} 2$, a novel human $\mathrm{MCH}$ receptor. J. Biol. Chem. 2001, 276, 20125-20129. [CrossRef]

54. Sailer, A.W.; Sano, H.; Zeng, Z.; McDonald, T.P.; Pan, J.; Pong, S.-S.; Feighner, S.D.; Tan, C.P.; Fukami, T.; Iwaasa, H.; et al. Identification and characterization of a second melanin-concentrating hormone receptor, MCH-2R. Proc. Natl. Acad. Sci. USA 2001, 98, 7564-7569. [CrossRef] [PubMed]

55. Schlumberger, S.E.; Talke-Messerer, C.; Zumsteg, U.; Eberle, A.N. Expression of receptors for melanin-concentrating hormone $(\mathrm{MCH})$ in different tissues and cell lines. J. Recept. Signal Transduct. Res. 2002, 22, 509-531. [CrossRef]

56. Fried, S.; O'Neill, K.; Hawes, B.E. Cloning and characterization of rhesus monkey MCH-R1 and MCH-R2. Peptides 2002, 23, 1401-1408. [CrossRef]

57. Tan, C.P.; Sanob, H.; Iwaasab, H.; Pana, J.; Sailer, A.W.; Hreniuk, D.L.; Feighner, S.D.; Palyha, O.C.; Ponga, S.-S.; Figueroa, D.J.; et al. Melanin-concentrating hormone receptor subtypes 1 and 2: Species-specific gene expression. Genomics 2002, 79, 785-792. [CrossRef]

58. Al Massadi, O.; Lopez, M.; Tschop, M.; Dieguez, C.; Nogueiras, R. Current Understanding of the Hypothalamic Ghrelin Pathways Inducing Appetite and Adiposity. Trends Neurosci. 2017, 40, 167-180. [CrossRef]

59. Belgardt, B.F.; Bruning, J.C. CNS leptin and insulin action in the control of energy homeostasis. Ann. N. Y. Acad. Sci. 2010, 1212, 97-113. [CrossRef]

60. Waterson, M.J.; Horvath, T.L. Neuronal Regulation of Energy Homeostasis: Beyond the Hypothalamus and Feeding. Cell Metab. 2015, 22, 962-970. [CrossRef]

61. Huang, P.L. A comprehensive definition for metabolic syndrome. Dis. Model. Mech. 2009, 2, 231-237. [CrossRef] [PubMed]

62. Zimmet, P.; Alberti, G.; Kaufman, F.; Tajima, N.; Silink, M.; Arslanian, S.; Wong, G.; Bennett, P.; Shaw, J.; Caprio, S.; et al. International Diabetes Federation Task Force on Epidemiology and Prevention of Diabetes. The metabolic syndrome in children and adolescents. Lancet 2007, 369, 2059-2061. [CrossRef]

63. Williams, E.P.; Mesidor, M.; Winters, K.; Dubbert, P.M.; Wyatt, S.B. Overweight and Obesity: Prevalence, Consequences, and Causes of a Growing Public Health Problem. Curr. Obes. Rep. 2015, 4, 363-370. [CrossRef] [PubMed] 
64. NCD Risk Factor Collaboration. Worldwide trends in body-mass index, underweight, overweight, and obesity from 1975 to 2016 : A pooled analysis of 2416 population-based measurement studies in 128.9 million children, adolescents, and adults. Lancet 2017, 390, 2627-2642. [CrossRef]

65. Olshansky, S.J.; Passaro, D.J.; Hershow, R.C.; Layden, J.; Carnes, B.A.; Brody, J.; Hayflick, L.; Butler, R.N.; Allison, D.; Ludwig, D. A Potential Decline in Life Expectancy in the United States in the 21st Century. N. Engl. J. Med. 2005, 352, 1138-1145. [CrossRef]

66. Bahjaoui-Bouhaddi, M.; Fellmann, D.; Griffond, B.; Bugnon, C. Insulin treatment stimulates the rat melanin-concentrating hormone-producing neurons. Neuropeptides 1994, 27, 251-258. [CrossRef]

67. Hausen, A.C.; Ruud, J.; Jiang, H.; Hess, S.; Varbanov, H.; Kloppenburg, P.; Bruning, J.C. Insulin-Dependent Activation of MCH Neurons Impairs Locomotor Activity and Insulin Sensitivity in Obesity. Cell Rep. 2016, 17, 2512-2521. [CrossRef]

68. Huang, Q.; Viale, A.; Picard, F.; Nahon, J.; Richard, D. Effects of leptin on melanin-concentrating hormone expression in the brain of lean and obese Lep(ob)/Lep(ob) mice. Neuroendocrinology 1999, 69, 145-153. [CrossRef]

69. Gavrila, A.; Chan, J.L.; Miller, L.C.; Heist, K.; Yiannakouris, N.; Mantzoros, C.S. Circulating melanin-concentrating hormone, agouti-related protein, and alpha-melanocyte-stimulating hormone levels in relation to body composition: Alterations in response to food deprivation and recombinant human leptin administration. J. Clin. Endocrinol. Metab. 2005, 90, 1047-1054. [CrossRef]

70. Bjursell, M.; Gerdin, A.K.; Ploj, K.; Svensson, D.; Svensson, L.; Oscarsson, J.; Snaith, M.; Tornell, J.; Bohlooly, Y.M. Melaninconcentrating hormone receptor 1 deficiency increases insulin sensitivity in obese leptin-deficient mice without affecting body weight. Diabetes 2006, 55, 725-733. [CrossRef]

71. Segal-Lieberman, G.; Bradley, R.L.; Kokkotou, E.; Carlson, M.; Trombly, D.J.; Wang, X.; Bates, S.; Myers, M.G.; Flier, J.S.; MaratosFlier, E. Melanin-concentrating hormone is a critical mediator of the leptin-deficient phenotype. Proc. Natl. Acad. Sci. USA 2003, 100, 10085-10090. [CrossRef] [PubMed]

72. $\mathrm{Wu}, \mathrm{Q} . ;$ Whiddon, B.B.; Palmiter, R.D. Ablation of neurons expressing agouti-related protein, but not melanin concentrating hormone, in leptin-deficient mice restores metabolic functions and fertility. Proc. Natl. Acad. Sci. USA 2012, 109, 3155-3160. [CrossRef] [PubMed]

73. Egecioglu, E.; Stenstrom, B.; Pinnock, S.B.; Tung, L.Y.; De La Cour, C.D.; Lindqvist, A.; Håkanson, R.; Syversen, U.; Chen, D.; Dickson, S.L. Hypothalamic gene expression following ghrelin therapy to gastrectomized rodents. Regul. Pept. 2008, 146, 176-182. [CrossRef] [PubMed]

74. Bjursell, M.; Egecioglu, E.; Gerdin, A.K.; Svensson, L.; Oscarsson, J.; Morgan, D.; Snaith, M.; Tornell, J.; Bohlooly, Y.M. Importance of melanin-concentrating hormone receptor for the acute effects of ghrelin. Biochem. Biophys. Res. Commun. 2005, 326, 759-765. [CrossRef]

75. Segal-Lieberman, G.; Rubinfeld, H.; Glick, M.; Kronfeld-Schor, N.; Shimon, I. Melanin-concentrating hormone stimulates human growth hormone secretion: A novel effect of MCH on the hypothalamic-pituitary axis. Am. J. Physiol. Endocrinol. Metab. 2006, 290, E982-E988. [CrossRef]

76. Takahashi, K.; Totsune, K.; Murakami, O.; Sone, M.; Satoh, F.; Kitamuro, T.; Noshiro, T.; Hayashi, Y.; Sasano, H.; Shibahara, S. Expression of melanin-concentrating hormone receptor messenger ribonucleic acid in tumor tissues of pheochromocytoma, ganglioneuroblastoma, and neuroblastoma. J. Clin. Endocrinol. Metab. 2001, 86, 369-374. [CrossRef]

77. Cvetkovic, V.; Brischoux, F.; Griffond, B.; Bernard, G.; Jacquemard, C.; Fellmann, D.; Risold, P.Y. Evidence of melanin-concentrating hormone-containing neurons supplying both cortical and neuroendocrine projections. Neuroscience 2003, 116, 31-35. [CrossRef]

78. Glick, M.; Segal-Lieberman, G.; Cohen, R.; Kronfeld-Schor, N. Chronic MCH infusion causes a decrease in energy expenditure and body temperature, and an increase in serum IGF-1 levels in mice. Endocrine 2009, 36, 479-485. [CrossRef]

79. Wade, G.N.; Jones, J.E. Neuroendocrinology of nutritional infertility. Am. J. Physiol. Regul. Integr. Comp. Physiol. 2004, 287, R1277-R1296. [CrossRef]

80. Williamson-Hughes, P.S.; Grove, K.L.; Smith, M.S. Melanin concentrating hormone (MCH): A novel neural pathway for regulation of GnRH neurons. Brain Res. 2005, 1041, 117-124. [CrossRef]

81. Chiocchio, S.R.; Gallardo, M.G.; Louzan, P.; Gutnisky, V.; Tramezzani, J.H. Melanin-concentrating hormone stimulates the release of luteinizing hormone-releasing hormone and gonadotropins in the female rat acting at both median eminence and pituitary levels. Biol. Reprod. 2001, 64, 1466-1472. [CrossRef] [PubMed]

82. Gonzalez, M.I.; Baker, B.I.; Wilson, C.A. Stimulatory effect of melanin-concentrating hormone on luteinising hormone release. Neuroendocrinology 1997, 66, 254-262. [CrossRef] [PubMed]

83. Murray, J.F.; Mercer, J.G.; Adan, R.A.; Datta, J.J.; Aldairy, C.; Moar, K.M.; Baker, B.I.; Stock, M.J.; Wilson, C.A. The effect of leptin on luteinizing hormone release is exerted in the zona incerta and mediated by melanin-concentrating hormone. J. Neuroendocr. 2000, 12, 1133-1139. [CrossRef] [PubMed]

84. Vazquez, M.J.; Romero-Ruiz, A.; Tena-Sempere, M. Roles of leptin in reproduction, pregnancy and polycystic ovary syndrome: Consensus knowledge and recent developments. Metabolism 2015, 64, 79-91. [CrossRef] [PubMed]

85. Dragano, N.; Milbank, E.; Lopez, M. Estradiol and appetite: To eat or not to eat. Mol. Metab. 2020, 42, 101061. [CrossRef]

86. Gonzalez-Garcia, I.G.; de Morentin, P.B.M.; Estévez-Salguero, Á.; Contreras, C.; Romero-Picó, A.; Fernø, J.; Nogueiras, R.; Diéguez, C.; Tena-Sempere, M.; Tovar, S.; et al. mTOR signaling in the arcuate nucleus of the hypothalamus mediates the anorectic action of estradiol. J. Endocrinol. 2018, 238, 177-186. [CrossRef]

87. Messina, M.M.; Boersma, G.; Overton, J.M.; Eckel, L.A. Estradiol decreases the orexigenic effect of melanin-concentrating hormone in ovariectomized rats. Physiol. Behav. 2006, 88, 523-528. [CrossRef] 
88. Chen, Y.; Hu, C.; Hsu, C.-K.; Zhang, Q.; Bi, C.; Asnicar, M.; Hsiung, H.M.; Fox, N.; Slieker, L.J.; Yang, D.D.; et al. Targeted disruption of the melanin-concentrating hormone receptor-1 results in hyperphagia and resistance to diet-induced obesity. Endocrinology 2002, 143, 2469-2477. [CrossRef]

89. Lopez, M.; Varela, L.; Vázquez, M.J.; Rodríguez-Cuenca, S.; González, C.R.; Velagapudi, V.R.; Morgan, D.A.; Schoenmakers, E.; Agassandian, K.; Lage, R.; et al. Hypothalamic AMPK and fatty acid metabolism mediate thyroid regulation of energy balance. Nat. Med. 2010, 16, 1001-1008. [CrossRef]

90. Capelli, V.; Dieguez, C.; Mittag, J.; Lopez, M. Thyroid wars: The rise of central actions. Trends Endocrinol. Metab. 2021, 32, 659-671. [CrossRef]

91. Harris, A.R.; Fang, S.L.; Azizi, F.; Lipworth, L.; Vagenakis, A.G.; Barverman, L.E. Effect of starvation on hypothalamic-pituitarythyroid function in the rat. Metabolism 1978, 27, 1074-1083. [CrossRef]

92. Chung, S.; Liao, X.H.; Di Cosmo, C.; Van Sande, J.; Wang, Z.; Refetoff, S.; Civelli, O. Disruption of the melanin-concentrating hormone receptor 1 (MCH1R) affects thyroid function. Endocrinology 2012, 153, 6145-6154. [CrossRef]

93. Kennedy, A.R.; Todd, J.F.; Stanley, S.A.; Abbott, C.R.; Small, C.J.; Ghatei, M.A.; Bloom, S.R. Melanin-concentrating hormone $(\mathrm{MCH})$ suppresses thyroid stimulating hormone (TSH) release, in vivo and in vitro, via the hypothalamus and the pituitary. Endocrinology 2001, 142, 3265-3268. [CrossRef]

94. Tsigos, C.; Chrousos, G.P. Hypothalamic-pituitary-adrenal axis, neuroendocrine factors and stress. J. Psychosom. Res. 2002, 53, 865-871. [CrossRef]

95. Jezova, D.; Bartanusz, V.; Westergren, I.; Johansson, B.B.; Rivier, J.; Vale, W.; Rivier, C. Rat melanin-concentrating hormone stimulates adrenocorticotropin secretion: Evidence for a site of action in brain regions protected by the blood-brain barrier. Endocrinology 1992, 130, 1024-1029. [CrossRef] [PubMed]

96. Kennedy, A.R.; Todd, J.F.; Dhillo, W.S.; Seal, L.J.; Ghatei, M.A.; O’Toole, C.P.; Jones, M.; Witty, D.; Winborne, K.; Riley, G.; et al. Effect of direct injection of melanin-concentrating hormone into the paraventricular nucleus: Further evidence for a stimulatory role in the adrenal axis via SLC-1. J. Neuroendocr. 2003, 15, 268-272. [CrossRef] [PubMed]

97. Smith, D.G.; Davis, R.J.; Rorick-Kehn, L.; Morin, M.; Witkin, J.M.; McKinzie, D.L.; Nomikos, G.G.; Gehlert, D.R. Melaninconcentrating hormone-1 receptor modulates neuroendocrine, behavioral, and corticolimbic neurochemical stress responses in mice. Neuropsychopharmacology 2006, 31, 1135-1145. [CrossRef]

98. Georgescu, D.; Sears, R.M.; Hommel, J.D.; Barrot, M.; Bolaños, C.A.; Marsh, D.J.; Bednarek, M.A.; Bibb, J.A.; Maratos-Flier, E.; Nestler, E.J.; et al. The hypothalamic neuropeptide melanin-concentrating hormone acts in the nucleus accumbens to modulate feeding behavior and forced-swim performance. J. Neurosci. Off. J. Soc. Neurosci. 2005, 25, 2933-2940. [CrossRef] 